\title{
ANAEMIA IN PREGNANCY
}

\author{
Jean M. ScotT, M.D. \\ Assistant Pathologist, Research Department, Royal Maternity Hospital, Rottenrow, Glasgow.
}

THOUGH one normally regards the estimation of hæmoglobin as one of the simplest procedures, it does seem rather anomalous that having obtained the result, it should then be difficult to decide whether certain pregnant women are actually anæmic or not. This is largely due to other changes which take place in the blood during pregnancy. As early as I88I Willcocks first noted the occurrence of hydræmia. Since then more detailed investigations have been carried out (Dieckmann and Wegner, 1934; Thomson, Hirsheimer, Gibson and Evans, 1938; Roscoe and Donaldson, 1946; Tysoe and Lowenstein 1950; Lund and Sisson, 1958), which have shown that while all elements of the blood increase in pregnancy, the increment in plasma volume is proportionately greater. For example Dieckmann and Wegner (1934) estimated that the plasma volume increased by $25 \%$, and the red cell and hæmoglobin mass by only 20 and $15 \%$ respectively, findings which explain the apparent drop in the hæmoglobin level noted by many other observers (Davidson, Fullerton and Campbell, 1935; Boycott, 1936; Widdowson, 1939; Davidson, Donaldson, Lindsay and McSorley, I943; Reid and Mackintosh, 1943; Elliott, 1944; Fullerton, Mair and Unsworth, 1944) and called the 'physiological anæmia' of pregnancy.

In a recent review of the literature Kerr and Davidson (1958) tabulated the salient features of this so-called physiological state, comparing and contrasting them with those of true iron deficiency anæmia. They found that a normal colour index, low-normal MCHC, normal or low-normal serum iron and low-serum-iron/iron-binding-capacity ratio, slightly raised reticulocyte count and slightly increased free erythrocyte protoporphyrin had all been reported. Most authorities agreed that these findings were unlikely in a true anæmia and they attributed the lowered hæmoglobin level to hæmodilution. Adair, Dieckmann and Grant (1936) considered that only hæmoglobin values below $10 \mathrm{~g}$./ $/ 00 \mathrm{ml}$. could be considered abnormal, and Whitby and Britton (1953) and many others agreed with this. Holly (1953) on the other hand placed the level higher at I I.5 g./100 ml.

The problem is not simply defined, however, largely because the hydræmia is a progressive process. It appears towards the end of the first trimester, increases more rapidly thereafter an usually reaches a maximum around the thirty-sixth week. Towards term some slight reduction in plasma volume has been reported (Lund, 195 $\overrightarrow{\mathrm{E}}$ Cope, 1958). Thus the so-called threshold off anæmia in pregnancy is a variable one and maog authors have noted the falling curve of hæmoglobi levels throughout gestation and the slight rise jug before term (Evans, 1943; Elliott, 1944; Scott and Govan, 1949; Rath, Caton, Reid, Finch and Conroy, 1950; Giles and Burton, 1960).

Most of these surveys have covered large numbers of pregnant women and a fairly regular decline in the average hæmoglobin values is noted. More detailed analysis of individual patiente, however, reveals a more variable picture. Fo․ example Lund (195I) showed that the percengase increase in plasma volume varied from $14^{\circ} \%$ one patient to as much as $121 \%$ in another and in many of their cases Roscoe and Donaldson (I $\overline{9} 4$ (4) found the blood volume increase was not outside the range of non-pregnant controls. Even whe the blood volume was related to weight or surfage area and expressed in absolute terms, wide variations were still present.

Obviously, if one speaks of a lowered threshoted of anæmia in pregnancy one must use the term its broadest sense, realising that it cannot fie applied with any great accuracy to individual patients. This was generally acknowledged and up till recently the idea of a physiological anæma of pregnancy was accepted. It was then noted thet iron therapy could correct the fall in hæmoglob and even prevent its occurrence (Scott and Govas, 1949; Klopper and Ventura, I951; Benstead and Theobald, 1952; Davis and Jennison, 1954; Lillie, Gatenby and Moore, 1954; Fisher ang Biggs, 1955; Edgar and Rice, 1956; Kerr and Davidson, 1958), evidence strongly against a so-called physiological process. Large numbets of otherwise normal pregnant women wewe followed throughout gestation, no anæmias beiag included. Some were given iron therapy and tree others left untreated or given a placebo. Not onfy did iron therapy eliminate the typical falling curke of hæmoglobin levels, but in treated cases tie hæmoglobin reading at term was higher than that 
found initially. Even when treatment was delayed till the twenty-fourth week Benstead and Theobald (1952) and Kerr and Davidson (1958) showed that the developing 'physiological anæmia' could be corrected and they recommended that all pregnant women should be given iron from the twentyfourth week onwards. More recently Giles and Burton (1960) stated that "the hæmoglobin of a normal woman in late pregnancy should be at least $80 \%$ (i $.8 \mathrm{~g} . / 100 \mathrm{ml}$.) '.

Possibly some reservation ought to be made here. Surveys en masse, as above, are not concerned with the treatment of patients as individuals. They deal merely with hæmoglobin levels, which are purely relative, for as Benstead and Theobald (I952) pointed out, no one really knows what happens to the blood volume when the hæmoglobin begins to rise. Moreover the rise is not equal in all patients. Scott and Govan (1949) divided their cases into three groups, $40 \%$ who improved, $52 \%$ who showed no change and $8 \%$ who deteriorated. Hamilton and Wright (1942) showed similar findings, but more patients deteriorated. Other reviews mention anything from a 10 to $20 \%$ failure-rate with patients still anæmic at term (Fisher and Biggs, 1955; Edgar and Rice, 1956); and Kerr and Davidson (1958) attributed these to either $(a)$ a failure to take iron, (b) failure to absorb it, (c) a mild folic acid deficiency, or $(d)$ a large increase in plasma volume. A number of patients may be included in the first two categories, but the remainder are not explained wholly by the third since Giles and Burton (I960) had failures even in their folic acid and iron-treated series. These authors noted that in at least $20 \%$ of the patients who remained ' anæmic' despite treatment, there was a sharp rise in hæmoglobin after delivery and they felt tempted to attribute the persistently low antepartum values to hypervolæmia.

This certainly seems reasonable. In a survey covering $\mathrm{I}_{32}$ women throughout gestation, Lund and Sisson (1958) found as many as $20 \%$ were actually hypervolæmic. To raise or maintain their hæmoglobin levels would mean, of necessity, a tremendous increase in total hæmoglobin mass and could lead to further complications, for Hamilton (1950) has shown that the relative decrease in cellular elements, secondary to hydræmia, produces a fall in blood viscosity. Moreover, as the viscosity fell the cardiac output rose. By this means she felt some mechanical relief was given to the heart, and, it may be, that the persistently low hæmoglobin values in hypervolæmic patients represent some such protective mechanism and are not the result of failure to respond.

In this respect it is also interesting to note that
Allaire and Campagna (196r) found normal iron storage in four patients with hæmoglobin values between 7.6 and $10 \mathrm{~g} . / 100 \mathrm{ml}$. Unfortunately blood volume estimations were not made on these patients, but such a combined study might prove enlightening.

Iron stores are usually reduced in pregnancy (Holly and Grund, 1959; Allaire and Campagna, I96r). Once iron therapy is instituted however, stainable iron begins to appear in the marrow and the majority of patients show a rise in hæmoglobin. These authors regard this as further evidence that iron deficiency exists. According to them one should aim at maintaining normal iron stores throughout pregnancy, irrespective of the increase in total hæmoglobin mass. In hypervolæmic patients this would entail the uptake of a considerable amount of iron, if it were possible, and might lead to iron overload in the puerperium, when the blood volume returns to normal and the mother receives a 'pay-back' of at least $500 \mathrm{mg}$. of iron from the reduction in her own hæmoglobin mass (Rath and others, 1950). According to Hahn (1937) this amount of iron would represent a 50\% increase above normal in available reserves.

Obviously this problem requires further investigation. According to the British Medical fournal (1958) there is now strong evidence that excessive deposits of hæmosiderin cannot produce hæmochromatosis (Cappell, Hutchison and Jowett, 1957). The only effects of excessive accumulation of iron might be the relative deficit of tissue antioxidants, especially vitamin $\mathrm{E}$ (Sisson and Lund, 1957).

Until more is known about blood viscosity and iron storage in pregnancy, one wonders whether the maintainance of a hæmoglobin level of over $80 \%$ in all pregnant women (Giles and Burton, 1960 ) is the ideal and whether we should strive to achieve this. Certainly there is no doubt that many pregnant British women have a latent iron deficiency and compared with their Australian sisters are in a poorer state of iron nutrition (Morgan, 196r). On the other hand if routine iron therapy is not instituted, it is difficult in a busy antenatal clinic to recognize early irondeficiency states. Assessment of body iron stores and blood volume estimations, though helpful in the odd case, cannot be regarded as routine procedures. Serum iron levels and even MCHC values are not good indicators of iron store depletion (Allaire and Campagna, 196r) though a rise in the former and a fall in the total ironbinding capacity with iron therapy can be taken as biochemical evidence of an iron deficiency state (Morgan, 196r). Neither of these methods would however be recommended as a routine test and both entail repeat estimations. One must 
TABLE I

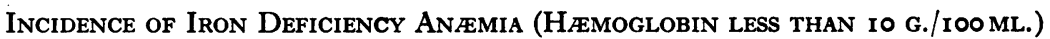

\begin{tabular}{|c|c|c|c|c|c|}
\hline Authors & & Year & Centre & $\begin{array}{c}\text { No. } \\
\text { Examined }\end{array}$ & $\begin{array}{c}\% \\
\text { Incidence }\end{array}$ \\
\hline $\begin{array}{l}\text { Reid and Mackintosh } \\
\text { Davidson and others } \\
\text { Fullerton and others } \\
\text { Scott and Govan .. } \\
\text { Scott .. . . } \\
\text { Lund . } \\
\text { Walsh and others. } \\
\text { Doyle and McGrath } \\
\text { Hapke and others } \\
\text { MacGregor }\end{array}$ & $\begin{array}{l}. \\
\ldots \\
\cdots \\
\cdots \\
\cdots \\
\cdots \\
\cdots\end{array}$ & $\begin{array}{l}1937 \\
1935 \\
1944 \\
1949 \\
1960 \\
1951 \\
1953 \\
1954 \\
1960 \\
1961\end{array}$ & $\begin{array}{l}\text { Stockport } \\
\text { Aberdeen } \\
\text { Glasgow } \\
\text { N" } \\
\text { New Orleans, U.S.A. } \\
\text { Australia } \\
\text { Dublin } \\
\text { Ohio, U.S.A. } \\
\text { Mombasa }\end{array}$ & $\begin{array}{r}1,108 \\
819 \\
301 \\
4,595 \\
5,218 \\
4,015 \\
-\overline{1,000} \\
-\overline{3,950}\end{array}$ & $\begin{array}{c}10.2 \\
17.5 \\
3.9 \\
17.6 \\
14.4 \\
20.0 \\
3.0 \\
31.4 \\
12.0 \\
29.6^{*}\end{array}$ \\
\hline
\end{tabular}

look for a simpler method of screening. Elliot (I944) noted that some patients with hæmoglobin readings less than $65 \%$ (Haldane) had no anisocytosis in their blood films. He attributed this to hydræmia and felt that the absence of anisocytosis was a significant finding. Some degree of anisocytosis is present in all normal pregnancies, but allowing for this Boycott (1936) claimed that an abnormal degree was more significant than a fall in the hæmoglobin level. In our experience this is one of the most helpful aids in diagnosis and one must learn to distinguish it from the picture seen after iron therapy, when well rounded, well hæmoglobinised macrocytes appear in the peripheral blood.

\section{Iron deficiency anæmia Incidence}

This, the commonest anæmia in pregnancy, is also one of its commonest complications. Yet it seems to have attracted little attention till the early thirties, when people began to take an interest in antenatal hæmoglobin levels. Many surveys have since been published and the results of some are included in Table $\mathrm{r}$. The majority of authors have accepted a hæmoglobin of $10 \mathrm{~g}$./ $100 \mathrm{ml}$. or $70 \%$ (Haldane) as the level at which anæmia becomes clinically significant. In MacGregor's series (I96r), however, anæmia was so prevalent in Mombasa that only values under $9 \mathrm{~g}$./100 $\mathrm{ml}$. were considered. Dublin has the highest incidence in the British Isles (Doyle and McGrath, 1954) and throughout the world Australia has the lowest. In America results vary considerably. Lund's series (I95I) shows a relatively high incidence and it is interesting to note that $90 \%$ of his patients were negroes. Repeat surveys carried out in Edinburgh, Aberdeen and Glasgow show a reduced incidence of anæmia. The most striking improvement, noted in Aberdeen between the years 1934 and 1944, was, as in Edinburgh, attributed to the introduc- tion of the wartime national loaf and its highe iron content (Davidson, Donaldson, Lindsay and Roscoe, 1944; Fullerton, Mair and Unsworth 1944). It would be interesting to compare thes incidence of anæmia in these cities since flouri milling has become finer. In Glasgow, the most interesting feature of the repeat-survey was the decline in the number of severe anæmias. These were reduced by $75 \%$ (Scott, 196I) and it wos felt that early recognition and treatment of irot deficiency in its milder forms in earlier pregnancies was largely responsible for this.

\section{AEtiology}

The xtiology of the anæmia is obvious complex. Pregnancy alone is not the cause though its demands for iron have certainly to be corg sidered. Fullerton (1936) placed these at $905 \mathrm{mgt}$ of which $55^{\circ} \mathrm{mg}$. went to the uterus and its contents, $175 \mathrm{mg}$. to blood lost at parturition and I $80 \mathrm{mg}$. to lactation. He preferred to neglect the iron included in the increased maternal hæm globin mass (500 mg.) as it returned to the maternal stores after delivery, but Rath and othe (1950) showed it in their equation. They also calculated the daily requirements for iron in each trimester, but made no allowance for blood loss at delivery and in the puerperium or the require ments of lactation.

The total demands of pregnancy are therefo probably in the region of $1,405 \mathrm{mg}$. On the credist side there is the post-partum hæmoglobin decreass (500 mg.) and the saving due to at least nine months amenorrhœa, calculated at $9 \times 25 \mathrm{mg}$., i.ẹ $225 \mathrm{mg}$. (Fowler and Barer, 1935). Thus compared with the nulliparous female the pregnant womat has a final deficit of $680 \mathrm{mg}$. if she breast-feed her baby, or $500 \mathrm{mg}$. if otherwise.

Apart from multiple pregnancies, where the iron requirements are proportionately increase $\Phi_{3}$ these demands are equal in all women. Whether 
anæmia develops or not largely depends on three main factors:-

(I) Iron stores. These, we know, are markedly depleted in the majority of anæmic women at their first visit to the clinic (Allaire and Campagna, 1961) and this suggests some pre-existing deficiency. Menstrual histories are invariably normal and in temperate climates complications apart from cardiac disease are few (Scott, I96I). The social background on the other hand seems to be more important. In a survey paying special attention to diet and housing, Doyle and McGrath (1953) found an incidence of anæmia of $83 \%$ in badly-run homes compared with $30 \%$ in well-run. They concluded that social circumstances were not entirely responsible, but had a definite influence on the incidence of anæmia. Their findings brought up to date similar reports by Reid and Mackintosh (1937) and Fullerton (1936). In Glasgow, we have also noted that anæmia is more prevalent among unmarried primiparæ (Scott, I96r) and it was considered that this was largely a reflection of their social background.

In tropical countries in addition to the poor dietary intake from childhood (de Langhen and Lichtenstein, 1936; Manson-Bahr, 1940; Trowell, 1942), the presence of parasites in the blood and intestine in a high percentage of the population (Berry, 1955; Schofield, 1957) is also important. Where the climate is humid, some iron may be lost in sweat (Foy and Kondi, 1957; Hussain and Patwardhan, 1959) and in negro populations genetic defects may give rise to anæmic states. For example, cases of sickle-cell anæmia frequently only come to light during a pregnancy (Edington and Lehmann, 1954; Smith and Conley, 1954). Abrams (1959) carried out routine screening of antenatal patients and found the sickle-cell trait to be fairly common, but sickle-cell anæmia and sickle-cell $\mathrm{C}$ disease, which produce symptoms, were relatively infrequent (Abrams and Schwartz, 1959). With the influx of West Indians into this country, one must be aware of this complication (Chanarin, MacGibbon, O'Sullivan and Mollin, 1959) and attention has also been drawn to it in a Lancet Editorial (1959).

Apart from local conditions and social class, one has always felt that in multipara the drain of repeated pregnancies must deplete the iron reserves. Yet investigations in the past into age and parity have all yielded contradictory results (Reid and Mackintosh, 1937; Fullerton and others, 1944; Scott and Sovan, 1949; Doyle and McGrath 1954; Kerr and Davidson, 1958). More recently, we suspected that rapidly occurring pregnancies, bringing about a negative iron balance, were more important than the actual parity itself and an attempt was made to relate the parity at which anæmia first appeared to the average delivery interval between babies (Scott, I96r). It was found that the shorter the interval the lower the parity at which the woman became anæmic. Eventually, however, longer intervals between babies did not prevent the higher-parous woman becoming anæmic.

(2) Absorption of iron. So far only one side of the problem, namely the state of the iron reserves, has been considered. The second main determining influence is the ability of the mother to increase her iron absorption during pregnancy. (Balfour, Hahn, Bale, Pommerenke and Whipple, 1942; Jasinski and Dierner, 1952). This increase may be anything from two to ten times normal and reaches a maximum in the last trimester. Unfortunately, however, in a number of instances adequate absorption does not occur.

It may be that the diet is deficient in iron. Figures for this country do not suggest that any marked deficiency is common (Kerr and Davidson, 1958), but in Uganda, Trowell and Muwazi (I945) found that some native diets contained as little as $4 \mathrm{mg}$. daily. These compare poorly with the standard of $15 \mathrm{mg}$. laid down by the Nutrition Committee of the B.M.A. in 1950, but it should be remenbered that even the latter figure has no reference to adequate absorption. What is more important is any imbalance in the diet, such as an excess of phytic acid or a high phosphate content, which may reduce absorption by forming insoluble iron compounds (Sharpe, Peacock, Cooke and Harris, 1950). On the other hand high vitamin C levels aid absorption (Moore, 1955) and may even partially correct the anæmia (Scott and Govan, 1949). It is interesting to note that vitamin C levels in the plasma are generally low in pregnancy (Hoch and Marrack, 1948) and a linked deficiency is a possibility.

Other factors too may influence iron absorption. It is well known that gastric acidity is reduced in pregnancy (Strauss and Castle, 1932; Goodall and Gottlieb, 1936; Murray, Erskine and Fielding, 1957) and diminished absorption was formerly attributed to this. Recent work on non-pregnant subjects (Moore, r955; Callender, Mallett and Smith, 1957; Smith and Mallett, I957) shows no correlation between achlorhydria and the absorption of iron either in anæmias or in controls. In pregnancy the position, as yet, is not so clear.

Certainly gastro-intestinal upsets are more frequent in gravid women. About one out of every five suffers from morning sickness and in those attending our antenatal blood clinic the figure is nearer $50 \%$. The symptoms are usually more pronounced in these cases and dietary intakes are frequently reduced, especially of foods rich in iron. 
(3) Erythropoietic activity: The state of the erythroid tissues themselves is also important. There are reports in the literature of œstrogens depressing erythropoiesis (Arnold, r939; Crafts, 1941), but Karnaky (1947) found no evidence of this when he gave stilbcestrol to a large number of pregnant women. On the other hand, in a recent radio-iron study of plasma and red-cell turnover rates in four normal gravid women, Holly and Grund (1959) found evidence to suggest that erythropoiesis was actually depressed in pregnancy. Pritchard and Adams (1960) could not conceive such a state of affairs, nor reconcile it with the obvious increase in total hæmoglobin and red cell mass. They repeated the work and found that erythropoiesis was actually accelerated. This agrees with bone marrow studies of Callender (1946) and others.

Thus if increased erythropoiesis is a necessity in normal pregnancy, it is not surprising that depressant effects should be more rapidly apparent. This is true of infections in pregnancy, and in pre-eclamptic toxæmia and chronic nephritis lower hæmoglobin readings have also been recorded (Moore and Pillman-Williams, 1936). It is likely that with infection some defect in synthesis occurs similar to that reported in nonpregnant cases (Saifi and Vaughan, 1944; Cartwright, Lauritsen, Jones, Merrill and Wintrobe, 1946).

\section{Clinical findings}

It is not proposed to consider these in any detail here, except to mention that few patients really complain of symptoms relative to anæmia. Though symptoms are present, they are usually related to and accepted as a normal accompaniment of pregnancy by the patient and unless routine hæmoglobin checks are made, many cases of anæmia may well be missed (Scott, 1959).

\section{Morphology}

The appearances vary only slightly from those of ordinary iron deficiency anæmia. Due to the hæmodilution of pregnancy, there is usually less anisocytosis and hypochromia than one would expect at each corresponding hæmoglobin level and allowance has to be made for this in the assessment of blood films. Occasionally in untreated severe anæmias with hæmoglobin levels of $6 \mathrm{~g} . / 100 \mathrm{ml}$. or under, reticulocyte counts of 3 to $4 \%$ have been found. The possibility of a hæmolytic factor has been investigated but this has never been proved. These cases also show fairly numerous normoblasts, myelocytes and metamyelocytes in their buffy coats and we have attributed the early appearance of these cells in the blood to the marked reactive change present in the marrow. Certainly the marrows tend to $\stackrel{\mathscr{Q}}{\mathscr{B}} \mathrm{e}$ very cellular and show a more primitive, but stall normoblastic form of erythropoiesis (Scott a fd $_{0}$ Govan, 1952).

\section{Treatment}

The ideal form of therapy is oral iron and should be commenced early in pregnancy to effective. Blood volume increases and fœtal demands for iron may even mask for a time a apparent rise in the hæmoglobin level (Scott affd Govan, 1949). Apart from the cost, the form cof iron to be given seems to matter little (O'Sulliva, Higgins and Wilkinson, I955; Brumfitt, 1959) and intolerance to any one preparation appears to $\overrightarrow{\mathrm{gse}}$ largely psychological in origin (Kerr and Davidsen, I958).

In practice, however, failures with oral irojn amount to between 10 and $20 \%$, mainly becaußse of gastric intolerance, less frequently frem irregular therapy and occasionally from failure i⿱⺈ absorption (Holly and Grund, 1959; Scott, 1958. These cases and others of severe anæmia near term present a problem to which intravenous iron and latterly intramuscular iron seemed to be the answer. The former, a saccharated iron oxiee, requires a careful injection technique and carries a fairly high rate of reactions which are occasiodasy quite severe (Nissim, 1947 and 1954; Slack Wilkinson, I949; Govan and Scott, I949; Libö, 1953). Nevertheless, it was universally adoptred soon after its introduction in 1947 and eventually only replaced by intramuscular iron 1954. This, an iron-dextran complex, is easy inject, causes few reactions on the whole and $\vec{\not}$ s almost as effective as intravenous iron (Scott aăd Govan, 1954; Cappell, Hutchison, Hendry and Conway, 1954; Baird and Podmore, 19 Jennison and Ellis, 1954; Scott, 1956). Absorption is via the lymphatics (Cappell and others, I954) and this accounts for the slightly slower response compared with intravenous iron.

For the next six years iron-dextran complex vas used fairly widely in the treatment of anæmia pregnancy. In this centre no patient with on allergic history or active infection was treated a a d no severe reactions occurred. The number $\rightarrow f$ transfusions for antenatal anæmia were reducedd both here (personal observation) and in other centres (Pritchard, 1959).

In I959 Richmond published his paper on the induction of sarcoma in the rat by iron-dextran complex. This work was confirmed and elaborated by Haddow and Horning (1960). Following $\mathrm{Qn}^{\mathrm{n}}$ Editorial in the British Medical Fournal (1960) the drug was withdrawn from general use. Four months later (1960) after careful re-assessment क्षf the whole position several well-known authorities 
TABLE 2

InCidenCE of Megaloblastic Anæmia

\begin{tabular}{|c|c|c|c|c|c|}
\hline Authors & & Year & Centre & $\begin{array}{c}\text { No. } \\
\text { Examined }\end{array}$ & $\begin{array}{c}\% \\
\text { Incidence }\end{array}$ \\
\hline $\begin{array}{l}\text { Davidson and others } \\
\text { Doyle and McGrath } \\
\text { Scott .. . } \\
\text { Butler . } \\
\text { Lowenstein and others } \\
\text { Cowan . } \\
\text { Forshaw and others } \\
\text { Giles and Shuttleworth } \\
\text { Giles and Burton.. } \\
\text { Ainley . . . . }\end{array}$ & $\begin{array}{l}\cdots \\
\cdots \\
\cdots \\
\cdots \\
\cdots \\
\cdots \\
\cdots \\
\cdots\end{array}$ & $\begin{array}{l}1942 \\
1953 \\
1954 \\
1959 \\
1955 \\
1957 \\
1957 \\
1958 \\
1960 \\
1961\end{array}$ & $\begin{array}{l}\text { Edinburgh } \\
\text { Dublin } \\
\text { Glasgow } \\
\text { America } \\
\text { Dumfries } \\
\text { Liverpool } \\
\text { North Staffordshire } \\
\text { Yorkshire ", }\end{array}$ & $\begin{array}{r}8,000 \\
3,000 \\
3,482 \\
5,464 \\
10,623 \\
1,850 \\
2,700 \\
3,199 \\
3,645 \\
10,629\end{array}$ & $\begin{array}{l}0.2 \\
0.27 \\
0.49 \\
0.53 \\
0.17 \\
0.5 \\
0.52 \\
2.8 \\
1.2 \\
1.09\end{array}$ \\
\hline
\end{tabular}

gave their conclusion ' that its use in the clinical dosage recommended carries a negligible risk and is probably less hazardous in other respects than intravenous iron preparations and blood transfusions' (Duthie, Girdwood, Hubble, MacGregor, Wayne, Wilson and Wilson, 1960). Since the publication of this letter most centres are now using iron-dextran complex, but as a later British Medical fournal Editorial (1960b) and Haddow (I960) pointed out, the possibility of any carcionogenic risk will not be apparent until another 15 years have passed.

Within the last few months a new intramuscular hæmatinic complex of iron sorbitol and citric acid with dextran has become available in this country (Jectofer-Lindvall and Andersson, I96r). The molecule is smaller than that of iron dextran (Imferon) and is absorbed directly into the blood stream from the injection site, reaching maximum values there within two to three hours (Andersson, 196I): $30 \%$ of the injected dose is lost in the urine and to allow for this a greater amount of iron would have to be injected. Unfortunately the molecule is less stable than that of iron dextran and the makers advise a maximum single dose of $100 \mathrm{mg}$. The number of injections has therefore to be increased, but so far no reactions of any import have been reported and the main advantage is that to date no carcinogenic effect has been noted in animals (Andersson, Lundin and Lundin, 196r). Trials are continuing, however, in several centres.

With intramuscular iron dextran the average case will show a rise in hæmoglobin of just under I g./100 $\mathrm{ml}$. in one week. Where labour is imminent and the anæmia severe, one must decide what improvement can be expected and whether transfusion is necessary. In this centre we aim to have the hæmoglobin over $9 \mathrm{~g} . / 100 \mathrm{ml}$. at least since our findings show that the risk to the mother above this level is probably no greater than the risk of transfusion itself (Brit. Med. $\mathcal{F}$., 1955; Bare and Sullivan, 1960).

\section{Megaloblastic Anæmias}

The earliest report on this severe ' anhæmia' of pregnancy was made in 1842 by Channing, an American obstetrician. Though occasional case reports appeared in the literature thereafter, no real survey was made until Osler published his paper in 1919. He noted that, unlike Addisonian pernicious anæmia, recovery. if it took place was permanent and the woman might escape the anæmia in subsequent pregnancies. Recovery in those days before transfusion, liver or folic acid therapy was by no means certain and the maternal mortality and stillbirth rates were high (Balfour, 1927; Wintrobe, 1942).

While still regarded as a rarity, reports on everincreasing numbers of cases began to appear in the literature. Stevenson (1938) described 30 cases in a 6-year survey, Davidson (195I) reported on 42 cases in II years, Thomson and Ungley (1951) found 46 cases in 17 years, and Lund (I95I) estimated that $\mathrm{I} \%$ of all anæmias were of this type. More recently the incidence has been expressed as a percentage of total deliveries and for comparison figures from various centres are listed in Table 2.

It can be seen that even in the last 7 years the incidence has been rising. It may be that this is due to a better understanding of the anæmia and earlier recognition. In Glasgow there is a slight rise between 1954 and 1959 , but this is not statistically significant (standard error 0.155). The figures include only cases of frank megaloblastic anæmia, whereas transitional forms of the anæmia are included in some of the other reports. This may partly account for the higher incidence elsewhere.

A seasonal variation has also been reported, a higher incidence being found in late winter and spring (Holly, 195I ; Forshaw, 1957; Thompson, 1957) and it has been related to the lower folic acid levels in the diet at this time of the year (Thompson, 1957). No seasonal pattern was found by 
Giles and Shuttleworth, 1958, or Gatenby and Lillie, r960.

Reports from abroad show an even higher incidence in India (Patel and Kocher, 1950) and Africa (Foy, Kondi, Hargreaves and Lowry, 1950; Berry, 1955), but in these countries complicating factors such as parasitic infestations and dietary deficiencies, especially of protein (Woodruff, 195I), probably play a part. A hæmolytic factor, possibly related to past malarial infection, has also been reported (Schofield, 1957). In Venezuela, Aguero and Layrisse (1958) found $4 \%$ of all pregnancy anæmias were of this type and none was a private patient.

\section{AEtiology}

This is largely a question of folic acid deficiency, due to either diminished intake or absorption, failure to utilize or increased demand. Chanarin and others (1959) carried out folic acid clearance and absorption tests in anæmic and non-anæmic pregnant women and controls. They found that compared with the controls the rate of clearance of injected folic acid was more rapid in normal pregnancy and with oral administration the absorption was poorer. In the megaloblastic anæmias of pregnancy these findings were even more marked. Girdwood and Delamore (196I) confirmed the greater part of this work, but disagreed that the cases of pregnancy anæmia showed much malabsorption. Both reports agreed that dietary deficiency was probably a minor factor here compared with the demands made by the fotus. In support of this Chanarin and others (1959) quoted the more rapid clearance noted in twin pregnancies and the higher incidence of the anæmia in cases of multiple pregnancy (Thompson and Ungley, r95 I ; Scott, r957; Giles and Shuttleworth, 1958).

While these tests point to a folic acid deficiency in normal pregnancy, they do not fully explain why certain pregnant women develop a megaloblastic anæmia. Some of the clearance tests in cases of twin pregnancy gave results similar to the megaloblastic anæmias-yet none of the former patients ever became anæmic (Chanarin and others, 1959). Cox, Matthews, Meynell, Cooke and Gaddie (1960) have also reported normal blood and marrow folic acid levels in a case of megaloblastic anæmia of pregnancy. Obviously there must be some other factor responsible for the megaloblastic change. Ainley (196I) and Giles (1960) suggested the possibility of an inherited predisposition and related this to the higher distribution of blood group A individuals in frankly megaloblastic anæmias. Day, Hall and Pease (I949) suspected some hormonal imbalance, but this has not been fully investigated. Badenoch,
Callender, Evans, Turnbull and Witts (1955) fee that resistance to the action of folic acid or other hæmopoietic factors may develop and it is we known that any additional stress, such as labou? may suddenly precipitate the megaloblastic change: Gatenby (1960) reports a higher incidence of megaloblastic anæmia of pregnancy in epileptic taking phenobarbitone and phenytoin and he quotes Chanarin, Elmes and Mollin (1958), whe suggested that these drugs interfere with the tissue metabolism of folic acid. It may be that in pregnancy equivalent conditions arise as a resulfe of folic acid deficiency itself and these eventuall $\vec{\phi}$ lead to a block in its own metabolism.

That folic acid deficiency is the main precipis tating factor in the onset of the anæmia has beex fairly well established now by Lowenstein, Pic and Philpott (1955), Giles and Burton (1960) anद्gु; Gatenby and Lillie (1960). These workers have shown that routine administration of 3 to $15 \mathrm{mg}$ of folic acid daily to women from the twenty/0 ninth week of pregnancy onwards, prevents th\& occurrence of the anæmia. The reverse is als $Q$ true. Any condition liable to aggravate a folic. acid deficiency is frequently found to precede the anæmia. Thus it is quite common for a megalo‥ blastic anæmia to follow some infection or an attack of late vomiting or viral hepatitis (Thompso and Ungley, I95 I Lowenstein, Pick and Philptt 1955; Scott, I957; Gatenby and Lillie, I960), opto develop in association with congenital spherocy tosis or hæmolytic anæmia (Davidson, r952\% O'Grady, Riva and Ritzenthaler, I953; Drurg and Geoghegan, 1957; Kohler, Meynell ane Cooke, I960; Delamore, Richmond and Davies $\overrightarrow{\text { क् }}$ 196r).

\section{Clinical Findings}

At one time this was regarded as an anæmia of late pregnancy and the puerperium. The onset. was generally described as rapid and the symptoms severe. Nowadays with earlier recognition of the anæmia, especially in its transitional form, more cases are being diagnosed before the thirtieth week, even before symptoms are apparent to the patient herself. One of the earliest signs is the failure of the hæmoglobin to rise after adequate. iron therapy and even with hæmoglobin reading over $10 \mathrm{~g}$./100 ml. megaloblastic change is still $i$ possibility. (Forshaw, Jones, Chisholm an\$ McGinley, 1957).

When the anæmia is severe splenic enlargement is noted in $30 \%$ of patients (Callender, 1944). Les? frequently the liver may be enlarged and purpurie eruptions and retinal hæmorrhages are occasionally found (Stevenson, 1938; Callender, 1944; Thompō son and Ungley, r95I). Glossitis is fairly commot and approximately half the patients have œdem 8 
and albuminuria. The symptomatology is otherwise that of any severe anæmia. In the differential diagnosis cardiac disease and even pre-eclamptic toxæmia (Scott and Govan, 1949) have to be considered.

\section{Recognition and Diagnostic Criteria}

The blood picture can be very variable, depending whether iron deficiency is present or not, but even when hypochromia is marked some large irregular macrocytes are usually found. Blue polychromasia (Davidson, 1959) or HowellJolly bodies (Hutchison and Smith, 1959) may also rouse suspicion. We have, however, noted these bodies in iron-deficiency anæmias of pregnancy responding to treatment. Usually one of the earliest changes in the blood is the presence of giant multi-segmented polymorphs and it is also interesting to note that, apart from anisocytosis, this is also the last abnormal feature to disappear with treatment. Foy and others (1950) noted this in Africans and suggested the possibility of a white cell maturation factor.

Unlike Addisonian pernicious anæmia, examination of a buffy coat or careful searching of a blood film frequently reveals the presence of megaloblasts and marrow puncture can be obviated. Sometimes only transitional cells are seen in the blood and though megaloblasts are usually found, when the marrow is examined, we have on occasions been unable to make a definite diagnosis even then. In these cases therapeutic trials with folic acid show a good reticulocyte response.

Much time is spent at present by the hæmatologist in attempting to give a firm diagnosis in transitional forms of the anæmia. Microbiological assays are of little help to him as yet, and it was hoped that tests covering the urinary excretion of formiminoglutamic acid (FIGLU) might be more useful (Lubhy, Cooperman and Teller, 1959). So far our results in transitional anæmias have met with little success and Spray and Witts (1959) report similar difficulties. They stated that gross deficiency of folic acid sufficient to cause megaloblastic change is probably necessary before the excretion of FIGLU increases, even in response to histidine.

White cell counts are usually low (Callender, 1944) and metamyelocytes and myelocytes may be present in the peripheral blood, especially in the puerperium when the anæmia is severe. Platelets may also be slightly diminished, though reports vary (Stevenson, 1938). Occasionally a slight rise in plasma bilirubin has been noted (Abramson, 1938; Stevenson, 1938), and serum iron levels are variable depending on the state of iron nutrition. A histamine-fast achlorhydria is unusual and repeat examinations in the puerperium have in all cases yielded free acid. Similar findings are reported by Callender (1944), Thompson and Ungley (195I) and Ainley (196r). Serum $B_{12}$ levels reveal a mild degree of deficiency in approximately $20 \%$ of patients, but this incidence is no more than that occurring in normal pregnant women (Heinrich, 1954; Spray and Witts, 1958). Fat absorption has been analysed (Badenoch and others, 1955; Lowenstein and others, 1955) and found to be normal, or slightly impaired in only a few cases (Giles and Shuttleworth, 1958).

\section{Therapy}

Treatment has certainly advanced from the days when the pregnancy had to be terminated and arsenic was the only hope. Liver therapy was a great advance, but cases still failed to respond, probably due to the low folic acid content in the preparations. Few failures have been reported with folic acid apart from those of Das Gupta, Chatterjea and Mathen (1949). Treatment is usually continued throughout pregnancy and for the first two to four weeks of the puerperium, depending on the duration of therapy.

Occasional responses to vitamin $\mathrm{B}_{12}$ have been reported in temporate climates (Nieweg, 1952), but this is most unusual (Day and others, r949; Davidson, I95 I ; Scott, I954). In the tropics and sub-tropics more cases respond to $\mathrm{B}_{12}$ (Chaudhuri, I95I; Patel and Kocher, 1950; Aguero and Layrisse, 1958) and in Africa a response to penicillin has been noted (Foy, Kondi and Hargreaves, I95I). Holly (I95I) also demonstrated remission with combined vitamins $B_{12}$ and $\mathrm{C}$ therapy. $\mathrm{He}$ suggested that vitamin $\mathrm{C}$ might aid the conversion of folic acid to citrovorum factor (folinic acid).

Apart from treatment of the actual anæmia the question of its prevention by routine administration of folic acid to all pregnant women ought to be considered. First suggested by Lowenstein and others (1955), this idea has gained support (Francis and Scott, 1959; Baines, 1959), but the arguments against it are well known. Ainley (196I) considered that older women ought to have additional vitamin $B_{12}$ in case serious neurological changes due to masked Addisonian pernicious anæmia should develop. In the same way cases of malabsorption syndrome or even gastric carcinoma (Gatenby and Lillie, I960) might also go undiagnosed. Addisonian pernicious anæmia is certainly uncommon in women of child-bearing age (Adams, 1958), and gastric carcinoma is rare, but it is doubtful whether one should run the risk of making a wrong diagnosis in such cases, especially in antenatal clinics where adequate hæmatological services are available. However, Gatenby and Lillie (1960) consider the risk is justifiable in 
TABLE 3

Percentage Incidence of Complications of Anemia

\begin{tabular}{|c|c|c|c|c|c|c|c|}
\hline \multicolumn{3}{|c|}{ Complication } & \multirow{2}{*}{$\left.\begin{array}{c}\begin{array}{c}\text { Ainley (r96r): } \\
\text { Megaloblastic } \\
\text { Anæmias }\end{array} \\
6.9(3.8)^{*} \\
2.6(0.9) \\
5.2(3.3)\end{array}\right\}$} & \multirow{2}{*}{$\begin{array}{l}\begin{array}{c}\text { Gatenby and } \\
\text { Lillie (r96o): } \\
\text { Megaloblastic } \\
\text { Anæmias }\end{array} \\
30.0\end{array}$} & \multirow{2}{*}{$\begin{array}{c}\text { McKenzie and } \\
\text { Abbot (196o): } \\
\text { Megaloblastic } \\
\text { Anæmias } \\
-\end{array}$} & \multirow{2}{*}{$\begin{array}{l}\text { Scott (196r): } \\
\text { All Anæmias } \\
45.0(27.0) \dagger\end{array}$} & \multirow{2}{*}{$\begin{array}{c}\text { MacGregor } \\
\text { (r96r): All } \\
\text { Anæmias } \\
\end{array}$} \\
\hline $\begin{array}{l}\text { Infection of birth p } \\
\text { Breast abscess } \\
\text { Urinary infection }\end{array}$ & $\begin{array}{l}\text { assa } \\
\cdots \\
\cdots\end{array}$ & $\begin{array}{l}\cdots \\
\cdots \\
\cdots\end{array}$ & & & & & \\
\hline $\begin{array}{l}\text { Hypertension and a } \\
\text { Hydramnios } \quad \ldots \\
\text { A.P.H... } \quad \ldots\end{array}$ & $\begin{array}{c}\text { bum } \\
\ldots \\
\cdots\end{array}$ & $\begin{array}{l}\text { aria } \\
\cdots \\
\cdots\end{array}$ & $\begin{array}{c}12.9(17.0) \\
3.4(2.3) \\
6.0(3.3)\end{array}$ & $\begin{array}{l}22.0(6.0)^{*} \\
9.0(1.2) \\
2.0\end{array}$ & $\begin{array}{l}42.5(12.7)^{*} \\
6.0(2.7)\end{array}$ & - & - \\
\hline $\begin{array}{l}\text { Stillbirths } \\
\text { Neonatal deaths }\end{array}$ & $\begin{array}{l}\cdots \\
\cdots\end{array}$ & $\begin{array}{l}\cdots \\
\cdots\end{array}$ & $\begin{array}{l}4.3(2.8) \\
0.9(1.0)\end{array}$ & $\begin{array}{l}3.0(2.9) \\
6.0(1.5)\end{array}$ & - & \} $10.6(0.5)\{$ & $\begin{array}{c}14.7(5.0) \ddagger \\
5.1(2.1)\end{array}$ \\
\hline $\begin{array}{l}\text { Premature labour } \\
\text { Prolonged labour }\end{array}$ & $\begin{array}{l}\cdots \\
\cdots\end{array}$ & $\begin{array}{l}\cdots \\
\cdots\end{array}$ & $3 . \overline{4}(5.6)$ & $\begin{array}{c}19.3(12.5) \\
1.0(1.7) \\
\text { (more than } \\
48 \text { hrs.) } \\
\text { 10.0 (13.0) } \\
2.0(22.0)\end{array}$ & - & $\begin{array}{l}11.0 \\
7.5(22.0) \\
\text { (more than } \\
26 \text { hrs.) } \\
21.0(11.0) \\
11.0(5.0)\end{array}$ & $\begin{array}{c}42.0(13.2) \\
- \\
-\end{array}$ \\
\hline Miscarriage & .. & $\cdots$ & - & - & - & II.O & - \\
\hline
\end{tabular}

* Figures in brackets represent the incidence of complications in the ordinary hospital population.

+ Figures in brackets represent the incidence of complications in 'low normal' (Hb. IO-I I g./ $100 \mathrm{ml}$.) controls. $\rightarrow$

$\ddagger$ Figures in brackets represent the incidence of complications in all patients with $\mathrm{Hb}$. values over $9 \mathrm{~g}$./ $100 \mathrm{ml}$.

multiple pregnancy, with its higher incidence of megaloblastic anæmia.

\section{Complications of Anæmia in General}

Before the introduction of safe blood transfusion and specific anti-anæmic therapy the prognosis for both mother and child was poor. Recently no maternal deaths have been recorded in this country, but even here one cannot afford to be complacent about the incidence of puerperal morbidity or the significantly raised miscarriage, prematurity and perinatal mortality rates. In Mombasa, where anæmia is prevalent, the full force of its effect is apparent (MacGregor, 196r). These conditions exist today, but the cases analysed in this department were actually drawn from the initial years of our survey (1946 and 1947), when follow-up methods at the ante-natal blood clinic were not so well organized. Today all these patients would at least have been transfused before delivery, if not fully investigated hæmatoo logically.

Further reference to Table 3 will show three of the surveys (Gatenby and Lillie, 1960 McKenzie and Abbot, 1960; Ainley, 1961) dea\$ solely with megaloblastic anæmia of pregnancyo While the complications are generally similar t $\Theta$ those mentioned above this type of anæmi $\overrightarrow{3}$ appears to be associated with a higher incidence of toxæmia, accidental hæmorrhage and possibly hydramnios. These relationships have onl. recently become apparent, as more cases of this anæmia come to light, but the underlying condi tions responsible for their occurrence remain as yet obscure. Whether or not there is a link with. folic acid or other deficiencies, there can be nQ doubt of the value of early diagnosis and treatment of anæmia in pregnancy and of the considerable part this has played in recent years in the

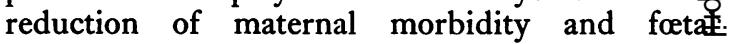
perinatal mortality.

\section{REFERENCES}

Abrams, J. (1959): Sickle Cell Trait and Pregnancy, Obstet. Gynec., 14, 123.

- and Schwartz, I. R. (1959): Sickle Cell Diseases in Pregnancy, Amer. Y. Obstet. Gynec., 77, r 324.

Abramson, L. (1938): Etats rappelant l'anémie pernicieuse durant la grossesse et les suites de couches, $A c t a$ me scand., 96, 319.

Adair, F. L., Dieckmann, W. J., and Grant, K. (1936): Anemia in Pregnancy, Amer. F. Obstet. Gynec., 32, 50.

Adams, J. F. (1958): Pregnancy and Addisonian Pernicious Anæmia, Scot. med. Y., 3, 21.

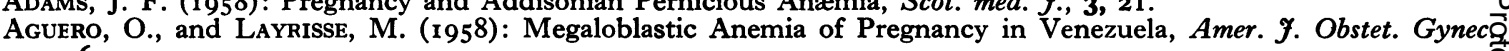

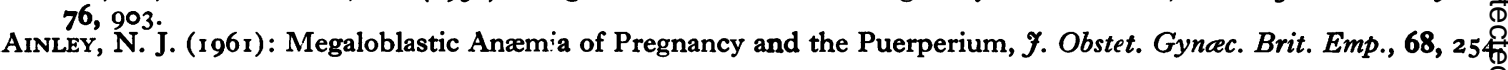


Allaire, B. I., and Campagna, F. A. (196r): Iron Deficiency Anæmia in Pregnancy; Evaluation of Diagnosis and Therapy by Bone Marrow Hæmosiderin, Obstet. Gynec., r7, 605 .

Andersson, N. S. E. (196r): Clinical Investigations on a New Intramuscular Hæmatinic, Brit. med. F., ii, 275. , Lundin, D., and Lundin, P. M. (196r): 'Clinical Investigations on a New I.M. Iron Hæmatinic, including an investigation on carcinogenic effect on animals'. Proceedings of the Eighth Congress of the European Society of Hæmatology. Part I. Vienna.

ArNold, O. (1939): Uber die Wirkung des synthetischen Brunststaffes Diäthylstilböstrol auf das Knochenmark und Blut des Hundes, Klin. Wschr., 18, 891.

Badenoch, J., Callender, S. T., Evans, J. R., Turnbull, A. L., and WitTs, L. J. (1955): Megaloblastic Anæmia of Pregnancy and the Puerperium, Brit. med. $\mathcal{Y} ., \mathrm{i}, 1245$.

Baines, J. H. E. (1959): Folic Acid Deficiency in Pregnancy, Lancet, ii, 1086.

BAIRD, I. McL., and Podmore, D. A. (1954): Intramuscular Iron Therapy in Iron Deficiency Anæmia, Ibid., ii, 942.

Balfour, M. I. (1927): Indian med. Gaz., 62, 491. (Quoted by J. F. Wilkinson (1932): Pernicious Anæmia and Pregnancy, F. Obstet. Gynac. Brit. Emp, 39, 293.)

Balfour, W. M., Hahn, P. F., Bale, W. F., Pommerenke, W. T., and Whipple, G. H. (i942): Fe 59 Absorption in Normal, Pregnancy Anæmia and Hæmachromatosis, f. exper. Med., 76, 15.

Bare, W. W., and Sullivan, A. A. (1960): Comparison of Intravenous Saccharated Iron Oxide and Whole Blood in the Treatment of Hypochromic Anemia of Pregnancy, Amer. F. Obstet. Gynec., 79, 279.

Benstead, N., and Theobald, G. W. (r952): Iron and the 'Physiological Anæmia of Pregnancy', Brit. med. Y., i, 407.

BerRy, C. G. (1955): Anæmia of Pregnancy in Africans of Lagos, Ibid., ii, 819.

Boycotт, J. A. (1936): Anæmia in Pregnancy, Lancet, i, 1165 .

British Metical Fournal (1955): Complications of Blood Transfusion, ii, 1493.

- (r958): Hæmosicerosis and Hæmachromatosis, i, 33 I.

- (r960a): Imferon and Cancer, $i, 788$.

- (r96ob): Imferon and Cancer, ii, 659.

BR umfitT, W. (1959): Iron Therapy in Primary Iron Deficiency Anæmia, Brit. med. $\mathcal{J} .$, ii, 473.

Butler, E. B. B. (1961): Personal communication.

Callender, S. T. E. (1944): A Critical Review of Pernicious Anæmia of Pregnancy, Quart. F. Med., 13, 75.

- (1946): The Bone Marrow in Pregnancy, f. Path. Bact., 58, 586.

Callender, S. T., Mallett, B. J., and SMith, M. D. (1957): Absorption of Hæmoglobin Iron, Brit. Y. Hamatol., 2, r.

Cappell, D. F., Hutchison, H. E., Hendry, E. B., and Conway, H. (1954): A New Carbohydrate-iron Hæmatinic for Intramuscular Use, Brit. med. $\mathcal{F}$., ii, 1255.

, and Jowetr, M. (1957): Transfusional Siderosis: the Effects of Excessive Iron Deposits on the Tissues, F. Path. Bact., 74, 245.

Cartwright, G. E., Lauritsen, M. A., Jones, P. J., Merrill, I. M., and Wintrobe, M. M. (i946): The Anæmia of Infection. I: Hypoferremia, Hypercupremia, and Alterations in Porphyrin Metabolism in Patients, $\mathfrak{F}$. clin. Invest., 25, 65 .

Chanarin, I., Elmes, P. C., and Mollin, D. L. (1958): Folic Acid Studies in Megaloblastic Anæmia Due to Primidone, Brit. med. F., ii, 80 .

—, MacGibbon, B. M., O’Sullivan, W. J., and Mollin, D. L. (I959): Folic Acid Deficiency in Pregnancy: Pathogenesis of the Megaloblastic Anæmias of Pregnancy, Lancet, ii, 634 .

Channing, W. (1842): New Engl. Quart. F. Med. Surg., I, 157 (quoted by Callender, 1944).

Chaudhuri, S. (195I): Vitamin $B_{12}$ in Megaloblastic Anæmia of Pregnancy and Tropical Nutritional Macrocytic Anæmia, Brit. med. $\mathcal{F}$., ii, 825 .

Cope, I. (1958): Plasma and Blood Volume Changes in Late and Prolonged Pregnancy, F. Obstet. Gynac. Brit. Emp., 65,877 .

Cox, E. V., Matthews, D., Meynell, M. J., Cooke, W. T., and Gaddie, R. (i 96o): Cyanocobalamin, Ascorbic Acid and Pteroylglutamates in Normal and Megaloblastic Bone Marrow, Blood, 15, 376.

Crafts, R. C. (194I): The Effect of Endocrines on the Formed Elements of the Blood. II: The Effect of Estrogens in the Dog and Monkey, Endocrinology, 29, 606.

Davidson, E. (1959): The Significance of Blue Polychromasia, Y. clin. Path., 12, 322.

Davidson, L. S. P., Fullerton, H. W., and Campbell, R. M. (1935): Nutritional Iron Deficiency Anæmia, Brit. med. .., ii, 195.

- Davis, L. J., and Innes, J. (1942): Megaloblastic Anæmia of Pregnancy and the Puerperium, Ibid., ii, 4253. , Donaldson, G. M. M., Lindsay, S. T., and McSorley, J. G. (1943): Nutritional Iron Deficiency Anæmia in Wartime, Part II, Ibid., ii, 95.

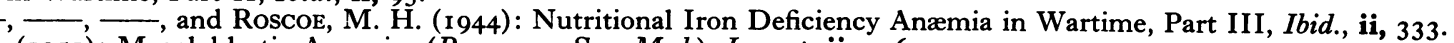
(195 I): Megaloblastic Anæmias (Proc. roy. Soc. Med.), Lancet, ii, ro67. (1952): Thirty Years' Experience of the Megaloblastic Anæmias, Edinb. med. F., 59, 315.

Davis, L. R., and Jennison, R. F. (1954): Response of the 'Physiological Anæmia' of Pregnancy to Iron Therapy, F. Obstet. Gynac. Brit. Emp., 6r, 103.

Day, L. A., Hall, E. H., and Pease, G. L. (1949): Macrocytic Anæmia of Pregnancy Refractory to Vitamin B ${ }_{12}$, Response to Folic Acid, Proc. Staff Meet. Mayo Clin., 24, 149.

Delamore, I. W., Richmond, J., and Davies, S. H. (I96r): Megaloblastic Anæmia in Congenital Spherocytosis, Brit. med. $\mathscr{f} ., \mathbf{i}, 543$.

Dieckmann, W. J., and Wegner, C. R. (r934): Blood in Normal Pregnancy; Blood and Plasma Volumes, Arch. intern. Med., 53, 7 I.

Doyle, G. D., and McGrath, J. (1954): Pregnancy Anæmia Survey, Coombe Lying-in Hospital, Dublin, 1953, Irish $\boldsymbol{F}$. med. Sci., 6, 414 .

Drury, M. I., and Geoghegan, F. (1957): Congenital Hæmolytic Anæmia Complicated by Megaloblastic Anæmia of Pregnancy, Brit. med. F., ii, 393. 
Duthie, J. J. R., Girdwood, R. H., Hubble, D., MacGregor, A. G., Wayne, E. J., Wilson, A., and Wilson, G. M⿸尸 (1960): Imferon and Cancer, Ibid., ii, 234.

Edgar, W., and Rice, H. M. (1956): Administration of Iron in Antenatal Clinics, Lancet, i, 599.

Edington, G. M., and Lehmann, H. (1954): A Case of Sickle Cell-Hæmoglobin C Disease and a Survey of Hæmæ globin C Incidence in West Africa, Trans. roy. Soc. trop. Med. Hyg., 48, 332.

ElliotT, G. A. (1944): The Anæmias of Pregnancy, F. Obstet. Gynac. Brit. Emp., 51, 198.

Evans, E. G. (1943): Anemia in Pregnancy, Illinois med. F., 84, 317.

Fisher, M., and Biggs, R. (1955): Iron Deficiency in Pregnancy, Brit. med. F., i, 385.

Forshaw, J. W. B. (1957): Seasonal Incidence of Megaloblastic Anæmia of Pregnancy and the Puerperium, Lance传 i, 1249 .

Jones, A. T., Chisholm, W. N., and McGinley, W. K. (1957): Megaloblastic Anæmia of Pregnancy and the Puerperium, F. Obstet. Gynae. Brit. Emp., 64, 255.

Fowler, W. M., and Barer, A. P. (1935): Iron Retention Following Use of Ferric Ammonium Citrate in Hypōi chromic Anemia, f. Amer. med. Ass., ro4, 144.

Foy, H., Kondi, A., Hargreaves, A., and Lowry, J. (1950): Anæmias of Africans in Kenya, Trans. roy. Soc. trop!

Med. Hyg., 43, 635. The Response of Megaloblastic Anæmia of Pregnancy to Crystalline Penicillin G, Brit med. $\mathcal{F} .$, i, 1108 .

- - (1957): Anæmias of the Tropics, Relation to Iron Intake, Absorption and Losses During Growth, Pres nancy, and Lactation, F. trop. Med. Hyg., 60, 105 .

Francis, H. H., and ScotT, J. S. (r959): Folic Acid Deficiency in Pregnancy, Lancet, ii, 1033. Fullerton, H. W. (1936): Anæmia in Poor Class Women with Special Reference to Pregnancy and Menstruatioiwi
Brit. med. F., ii, 523. , MaIR, M. I., and Unsworth, P. (1944): A Survey of the Hæmoglobin Levels of the Poor Classes in Aberdeece
Ibid., ii, 373.

Gatenby, P. B. B. (1960): Anticonvulsants as a Factor in Megaloblastic Anæmia of Pregnancy, Lancet, ii, roo4. N

-, and Lillie, E. W. (1960): Clinical Analysis of roo Cases of Severe Megaloblastic Anæmia of Pregnancy, Briț med. $\mathcal{F}$., ii, I I I I.

Giles, C., and Shuttleworth, E. M. (1958): Megaloblastic Anæmia of Pregnancy and the Puerperium, Lancet, ii, I34

- , and BurTon, H. (1960): Observations on Prevention and Diagnosis of Anæmia in Pregnancy, Brit. med. $\mathcal{F}$., ii, 636 .

- (1960): Blood Group Distribution in Megaloblastic Anæmia of Pregnancy, Lancet, ii, 1063.

Girdwood, R. H., and Delamore, I. W. (196I): Observations on Tests of Folic Acid Absorption and Clearance. Scot. med. F., 6, 44.

Goodall, J. R., and Gottlieb, R. (1936): The Association of Pregnancy, Hypochromic Anemia and Achlorhygifi Canad. med. Ass. F., N.S. 35, 50.

Govan, A. D. T., and ScotT, J. M. (1949): Intravenous Iron in the Treatment of Anæmia of Pregnancy, Lancet, i.

Das Gupta, C. R., Chatterjea, J. B., and Mathen, K. K. (1949): Folic Acid in Treatment of Macrocytic Anzoig in Pregnancy, Indian F. med. Res., 37, 455.

Haddow, A., and Horning, E. S. (1960): Carcogenicity of Iron Dextran Complex, f. nat. Cancer Inst., 24, I09.

(1960): Imferon and Cancer, Brit. med. $\mathcal{F}$., ii, $66_{3}$.

Hahn, P. F. (1937): Metabolism of Iron, Medicine, 16, 249.

Hamilton, H. A., and Wright, H. P. (1942): Development of Hypochromic Anæmia During Pregnancy, Lancę i, 184 .

Hamilton, H. F. H. (1950): Blood Viscosity in Pregnancy, F. Obstet. Gynac. Brit. Emp., 57, 530.

Hapke, F., Stauf, J. L., and Ullery, J. C. (1960): Parenteral Iron Therapy in Anemia of Pregnancy, Amer. F. Obstet. Gynec., 79, 5.

HeInRICH, H. C. (1954): Die Biochemischen Grundlagen der Diagnostik und Therapic der Vitamin B - Mange $_{12}$ zustände ( $B_{12}$-hypo-und avitaminosen) des Menschen und der Haustiere. II: Untersuchungen zum Vitamin $B$ -Stoffwechsel des Menschen während der Gravidtat und Lactation, Klin. Wschr., 32, 205.

Hoch, H., and Marrack, J. R. (1948): Composition of the Blood of Women During Pregnancy and After Deliverye F. Obstet. Gynac. Brit. Emp., I55, 1 .

Holly, R. G. (I95I): Megaloblastic Anemia of Pregnancy; Remission Following Therapy with Vitamin C and Big Proc. Soc. exp. Biol. (N.Y.), 78, 238.

- (1953): The Iron and Iron-binding Capacity of Serum and the Erythrocyte Protoporphyrin in Pregnancy; Ther Significance in the Diagnosis of Anæmia in Pregnancy and in Establishing Normal Hæmatological Values for Pregnancy, Obstet. Gynec., 2, I 19.

$\longrightarrow$, and Grund, W. J. (r959): Ferrodynamics During Pregnancy, Amer. F. Obstet. Gynec., 77, 731.

Hussain, R., and Patwardhan, V. N. (1959): Iron Content of Thermal Sweat in Iron Deficiency Anæmia, Lance i, 1073 .

Hutchison, H. E., and Ferguson Smith, M. A. (1959): The Significance of Howell-Jolly Bodies in Red Cell Prê cursors, $\mathcal{F}$. clin. Path., 12, $45 \mathrm{I}$.

JASINSKI, B., and DiERNER, E. (1952): Zur Frage der Häufigkeit des larvierten Eisenmangels bei Frauen, insbesonder\& bei Graviden und bei Wöchnerinnen, Gynacologia (Basel), 133, 293.

Jennison, R. F., and Ellis, H. R. (1954): Intramuscular Iron: A Clinical Trial in Pregnancy, Lancet, ii, r245.

KaRNAKY, J. K. (1947): The Effect of Estrogen (Stilboestrol) on the Formed Elements of the Blood in Womeff F. Obstet. Gynac. Brit. Emp., 54, 366.

Kerr, D. N. S., and Davidson, S. (1958): Prophylaxis of Iron Deficiency Anæmia of Pregnancy, Lancet, ii, $483 . \stackrel{\mathscr{O}}{+}$ Klopper, A., and Ventura, S. (1951): Iron Metabolism in Pregnancy, Brit. med. F., ii, 125 I.

Kohler, H. G., Meynell, M. J., and Cooke, W. T. (1960): Spherocytic Anæmia Complicated by Megaloblastê Anæmia of Pregnancy, Ibid., i, 779.

Lancet Editorial (1959): Sickle Cells, ii, 33 I . 
De Langhen, C. D., and Lichtenstein, A. (1936): In 'Stitt's Diagnosis, Prevention and Treatment of Tropical Diseases', 7th edit., 1945, p. 126r.

Librach, I. M. (I953): Toxic Reactions Due to Intravenous Iron, Brit. med. F., i, 2 I.

Lillie, E. W., Gatenby, P. B. B., and Moore, H. C. (1954): A Survey of Anæmia in 4,314 Cases of Pregnancy, Irish F. med. Sci., 6, 304 .

Lindvall, S., and AnDersson, N. S. E. (1961): 'Some Properties of a New Hæmatinic Complex of Iron, Sorbitol and Citrate for Intramuscular Use'. Proceedings of the Eighth Congress of the European Society of Hæmatology. Part I. Vienna.

Lowenstein, L., Pick, C., and Philpott, N. (r955): Megaloblastic Anemia of Pregnancy and the Puerperium, Amer. F. Obstet. Gynec., 70, 1309.

Luhby, A. L., Cooperman, J. M., and Teller, D. N. (1959): Urinary Excretion of Formaminoglutamic Acid, Amer. f. clin. Nutr., 7, 397.

Lund, C. J. (1951): Studies on the Iron Deficiency Anemia of Pregnancy, Amer. Y. Obstet. Gynec., 62, 947.

- and Sisson, T. R. C. (1958): Blood Volume and Anemia of Mother and Baby, Ibid., 76, I013.

MACGREGor, M. W. (I96I): Personal communication.

MackenziE, A., and Abbot, J. (1960): Megaloblastic Erythropoiesis in Pregnancy, Brit. med. F., ii, ir 44.

Manson-Bahr, P. H. (1940): In 'Stitt's Diagnosis, Prevention and Treatment of Tropical Diseases', 7th edit., 1945, p. $126 \mathrm{r}$.

Moore, C. V. (1955): The Importance of Nutritional Factors in the Pathogenesis of Iron Deficiency Anemia, Amer. F. clin. Nutr., 3, 3 .

Moore, J., and Pillman-Williams, E. M. (1936): Anæmia and Toxæmia of Pregnancy, Brit. med. F., ii, 528.

Morgan, E. H. (r96r): Plasma Iron and Hæmoglobin Levels in Pregnancy: The Effect of Oral Iron, Lancet, i, 9.

Murray, F. A., Erskine, J. P., and Fielding, J. (I957): Gastric Secretion in Pregnancy, f. Obstet. Gynaec. Brit. Emp., 64, 373.

NieweG, H. O. (1952): Megaloblastic Anæmia of Pregnancy, Lancet, ii, 491.

Nissim, J. A. (1947): Intravenous Administration of Iron, Ibid., ii, 49. (I954): Toxic Reactions After Intravenous Saccharated Iron Oxide in Man, Brit. med. $\mathscr{Y}$., i, 352.

O’Grady, J. W., Riva, H. L., and Ritzenthaler, J. G. (1953): Hemolytic Anemia in Pregnancy, Amer. F. Obstet. Gynec., 65,1338 .

OsLer, Sir WM. (1919): The Severe Anæmias of Pregnancy and the Postpartum State, Brit. med. Y., i, r.

O'Sullivan, D. J., Higgins, P. G., and Wilkinson, J. F. (I955): Oral Iron Compounds: A Therapeutic Comparison, Lancet, ii, 482.

Patel, J. C., and Kocher, B. R. (1950): Vitamin $B_{12}$ in Macrocytic Anæmia of Pregnancy and the Puerperium, Brit. med. Э., i, 924.

Pritchard, J. A. (1959): Anemia in Obstetrics and Gynecology: An Evaluation of Therapy with Parenteral Iron, Amer. F. Obstet. Gynec., 77, 74.

- and Adams, R. H. (1960): Erythrocyte Production and Destruction During Pregnancy, Amer. F. Obstet. Gynec. 79, 750.

Rath, C. E., Caton, W., Reid, D. E., Finch, C. A., and Conroy, L. (r950): Hematological Changes and Iron Metabolism in Normal Pregnancy, Surg. Gynec. Obstet., 90, 320.

Reid, W. J. S., and Mackintosh, J. M. (1943): Incidence of Anæmia in Pregnancy, Lancet, ii, 43.

Richmond, H. G. (1959): Induction of Sarcoma in the Rat by Iron Dextran Complex, Brit. med. $\mathcal{F}$., i, 947.

Roscoe, M. H., and Donaldson, G. M. M. (1946): Blood in Pregnancy, F. Obstet. Gynac. Brit. Emp., $53,527$.

Saifi, M. F., and Vaughan, J. (1944): Anæmia Associated with Infection, F. Path. Bact., 56, i89.

SchofIeld, F. D. (1957): Aspects of Nutritional Anæmia in Pregnancy in Gambia, Trans. roy. Soc. trop. Med. Hyg., 5I, 221 .

ScotT, J. M., and Govan, A. D. T. (1949a): Anæmia of Pregnancy in Glasgow and District, Brit. med. F., ii, ro83.

_- - - (1949b): Anæmia Simulating Pre-eclamptic Toxæmia, F. Obstet. Gynac. Brit. Emp., 56, 27.

- - (1952): The Bone Marrow in the Anæmia of Pregnancy, f. clin. Path., 5, 145.

- - - (1954): Anæmia of Pregnancy Treated with Intramuscular Iron, Brit. med. $\mathcal{f}$., ii, 1257.

- (1954): Therapy in the Megaloblastic Anæmias of Pregnancy, $\mathcal{F}$. Obstet. Gynac. Brit. Emp., $6 \mathbf{1}, 646$.

- (1956): Intramuscular Iron Therapy in Anæmia of Pregnancy, a Two-Year Survey, Brit. med. F., ii, 635.

- (1957): Folinic Acid in Megaloblastic Anæmia of Pregnancy, Ibid., ii, 270.

- (1959): Iron Deficiency Anæmia in Pregnancy, Med. Wld (Lond.), 91, 308.

(196I): Anemia in Pregnancy: A Ten-Year Survey, $\mathcal{Y}$. Amer. med. Wom. Ass., 16, I32.

Sharpe, L. M., Peacock, N. C., Cooke, R., and Harris, R. S. (I950): The Effect of Phytate and other Food Factors on Iron Absorption, $\mathcal{F}$. Nutr., 4I, 433 .

Sisson, T. R. C., and LuND, C. J. (I957): The Influence of Maternal Iron Deficiency on the Newborn, A.M.A. Y. Dis. Child., 94, 525.

SlaCk, H. G. B., and Wilkinson, J. F. (1949): Intravenous Treatment of Anæmia with an Iron-sucrose Preparation, Lancet, $\mathrm{i}, \mathrm{II}$.

Smith, E. W., and Conley, C. L. (1954): Clinical Features of the Genetic Variants of Sickle Cell Disease, Bull. Fohns Hopk. Hosp., 94, 289.

Smith, M. D., and Mallett, B. (1957): Iron Absorption Before and After Partial Gastrectomy, Clin. Sci., 16, 23.

SPRAY, G. H., and WITTS, L. J. (1958): Results of Three Years' Experience with Microbiological Assay of Vitamin $B_{12}$ in Serum, Brit. med. $\mathcal{F}$., i, 295.

- - (1959): Excretion of Formiminoglutamic Acid as an Index of Folic Acid Deficiency, Lancet, ii, 702.

Stevenson, E. M. K. (1938): Anæmia in Pregnancy and the Puerperium, Edinb. med. F., 45, 81.

Strauss, M. B., and Castle, W. B. (1932): Studies of Anemia in Pregnancy. I: Gastric Secretion in Pregnancy and the Puerperium, Amer. F. med. Sci., 184, 655.

Continued on page 235. 


\section{Summary}

I. Essential hypertension in pregnancy is defined.

2. Fallacies involved in the correct determination of the arterial blood-pressure are described.

3. The differential diagnosis of conditions giving rise to hypertension during pregnancy is outlined.
4. A review is given of the clinical course of pregnancy in hypertensive subjects, with the frequency and significance of incidental complications.

5. The management of pregnancy and labour in hypertensive patients is discussed.

6. The prognosis is described both during the immediate pregnancy and subsequently.

\section{REFERENCES}

Browne, F. J. (1935): 'Antenatal and Postnatal Care'. London: J. \& A. Churchill. , and Dodds, G. H. (1942): Pregnancy in the Patient with Chronic Hypertension, F. Obstet. Gynac. Brit. Emp., 49, $I$.

Browne, J. C. McC. (1958): The Significance of Hypertension in the Pregnant Woman, ' Symposium on Non-Toxæmic Hypertension in Pregnancy', p. 76. Ed.: N. Morris and J. C. McC. Browne. London: J. \& A. Churchill. , and Veall, N. (I953): The Maternal Placental Blood Flow in Normotensive and Hypertensive Women, $\mathfrak{F}$. Obstet. Gynac. Brit. Emp., 60, 141 .

Burwell, C. S. (1938): The Placenta as a Modified Arteriovenous Fistula, Considered in Relation to the Circulatory Adjustments to Pregnancy, Amer. F. med. Sci., 195, I.

Dodds, G. H. (1958): Prognosis for Subsequent Pregnancies in Patients with Essential Hypertension, ' Symposiu m on Non-Toxæmic Hypertension in Pregnancy', p. 207. Ed.: N. Morris and J. C. McC. Browne. London: J. \& A. Churchill.

Duff, R. S. (1 958): The Functional State of Peripheral Arterioles in Human Hypertension, Ibid., p. 25. Ed.: N. Morris and J. C. McC. Browne. London: J. \& A. Churchill.

Feeney, J. K. (1958): The Remote Prognosis of the Hypertension of Pregnancy, Ibid., p. 224. Ed.: N. Morris and J. C. McC. Browne. London: J. \& A. Churchill.

GAte, J. M. (1960): Fœtal Mortality in Essential Hypertension, Lancet, i, 901.

HARE, D. C., and KARN, M. N. (r929): An Investigation of Blood Pressure, Pulse Rate and the Response to Exercise During Norman Pregnancy, and Some Observations after Confinement, Quart. F. Med., $22,381$.

Johnson, G. T. (1958): The Course of Pregnancy Complicated by Essential Hypertension, 'Symposium on NonToxæmic Hypertension in Pregnancy', pp. 6r and 67. Ed.: N. Morris and J. C. McC. Browne. London: J. \& A. Churchill.

Masters, A. M., Dublin, L. I., and Marks, H. H. (1950): The Normal Blood Pressure Range and its Clinical Implications, F. Amer. med. Ass., 143, 1464.

Matthews, A. E. B ( 1961 ): Personal communication.

Morris, N., Osborne, S. B., and Payling Wright, H. (i956): Effective Uterine Blood Flow During Exercise in Normal and Pre-eclamptic Pregnancies, Lancet, ii, $48 \mathrm{I}$.

Morris, W. I. C. (1958): The Course of Pregnancy Complicated by Essential Hypertension, 'Symposium on NonToxæmic Hypertension in Pregnancy', p. 47. Ed.: N. Morris and J. C. McC. Browne. London: J. \& A. Churchill.

Pickering, G. W. (1955): 'High Blood Pressure', p. i81. London: J. \& A. Churchill.

Platt, R. (1959): The Nature of Essential Hypertension, Lancet, ii, 55.

Reed, D. E., and Teel, H. M. (1938): A Study of the 'Cold Test' in Normal and in Toxæmic Pregnancy, Amer. F. Obstet. Gynec., 35, 305 .

Taylor, H. C., Tillman, A. J. B., and Blanchard, J. (1954): Fœtal Losses in Hypertension and Pre-eclampsia, Obstet. Gynec., 3, 225.

Townsend, L. (r959): 'High Blood Pressure and Pregnancy'. Melbourne: University Press.

VArTan, C. K. (1958): The Significance of Hypertension in the Pregnant Woman, 'Symposium on Non-Toxæmic Hypertension in Pregnancy', pp. 86 and 87. Ed.: N. Morris and J. C. McC. Brown?. London: J. \& A. Churchill.

Continued from page $2 \mathrm{I} 3$.

Thompson, R. B., and Ungley, C. C. (I95I): Megaloblastic Anæmia of Pregnancy and the puerperium, Quart. $\mathcal{Y}$. Med., N.S. 20, 187.

- (1957): Seasonal Incidence of Megaloblastic Anæmia of Pregnancy and the Puerperium, Lancet, i, I I 7 I.

Thomson, K. J., Hirsheimer, A., Gibson, J. G., and Evans, W. A. (1938): Studies on the Circulation in Pregnancy. III: Blood Volumes in Normal Pregnant Women, Amer. $\mathcal{F}$. Obstet. Gynec., 36, 48.

Trowell, H. C. (1942): The Morphology of the Blood in Dimorphic Anæmia, Trans. roy. Soc. trop. Med. Hyg., 36, r 51 . , and Muwazi, E. M. K. (1945): A Contribution to the Study of Malnutrition in Central Africa: A Syndrome of Malignant Malnutrition, Ibid., 39, 229.

Tysoe, P. M., and Lowenstein, L. (I950): Blood Volume and Hematological Studies in Pregnancy and the Puerperium, Amer. F. Obstet. Gynec., 60, 1187.

Walsh, R. J., Arnold, B. J., Lancaster, H. O., Coote, M. A., and Cotter, H. (1953): National Health Research Council Spec. Rep. Ser. No. 5, quoted by Morgan (196r).

Whitby, L. E. H., and Britton, C. J. C. (1953): 'Disorders of the Blood', p. 3 I I. London: Churchill.

Widdowson, E. M. (1939): Iron Administration and Hæmoglobin Levels During Pregnancy, Lancet, ii, 640.

Willcocks, F. (1881): Some Comparative Observations in the Blood in Chlorosis and Pregnancy, Ibid., ii, 944.

Wintrobe, M. M. (1942): 'Clinical Hæmatology'. London: Henry Kimpton.

Woodruff, A. W. (1951): Anæmia of Pregnancy Ámong Africans in Nigeria, Brit. med. F., ii, 1415. 